IRA-International Journal of Management \& Social Sciences

ISSN 2455-2267; Vol.08, Issue 01 (July 2017)

Pg. no. 98-102

Institute of Research Advances

http://research-advances.org/index.php/RAJMSS

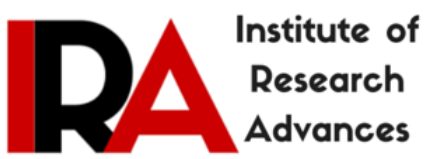

\title{
Social Worker Specialization: A Panacea to Nigerian Prisons Rehabilitation Service
}

\author{
Kehinde Adekunle Aliyu ${ }^{1}$, Jamaludin Mustaffa ${ }^{2} \&$ NorruzeyatiCheMohd Nasir ${ }^{3}$ \\ ${ }^{1,2,3}$ School of Applied Psychology, Social Work and Policy, Universiti Utara Malaysia, 06010 \\ UUM Sintok, Kedah, Malaysia.
}

Type of Review: Peer Reviewed.

DOI: http://dx.doi.org/10.21013/jmss.v8.n1.p11

\section{How to cite this paper:}

Aliyu, K., Mustaffa, J., \& Nasir, N. (2017). Social Worker Specialization: A Panacea to Nigerian Prisons Rehabilitation Service. IRA-International Journal of Management \& Social Sciences (ISSN 2455-2267), 8(1), 98-102. doi:http://dx.doi.org/10.21013/jmss.v8.n1.p11

(C) Institute of Research Advances.

\section{(c) BY-No}

This work is licensed under a Creative Commons Attribution-Non Commercial 4.0 International License subject to proper citation to the publication source of the work.

Disclaimer: The scholarly papers as reviewed and published by the Institute of Research Advances (IRA) are the views and opinions of their respective authors and are not the views or opinions of the IRA. The IRA disclaims of any harm or loss caused due to the published content to any party.

\footnotetext{
Institute of Research Advances is an institutional publisher member of Publishers Inter Linking Association Inc. (PILA-CrossRef), USA. The institute is an institutional signatory to the Budapest Open Access Initiative, Hungary advocating the open access of scientific and scholarly knowledge. The Institute is a registered content provider under Open Access Initiative Protocol for Metadata Harvesting (OAI-PMH).

The journal is indexed \& included in WorldCat Discovery Service (USA), CrossRef Metadata Search (USA), WorldCat (USA), OCLC (USA), Open J-Gate (India), EZB (Germany) Scilit (Switzerland), Airiti (China), Bielefeld Academic Search Engine (BASE) of Bielefeld University, Germany, PKP Index of Simon Fraser University, Canada.
} 


\begin{abstract}
Nigerian's prisons conditions is pathetic, a very dreadful and incompetent of assuring expected rehabilitation of inmates. There exists a general rareness of infrastructures, policies, and corruption in the system. Given this context, the main thrust of this study was to examine the specialization of social worker on the impact of prison rehabilitation programmes on the welfare of the inmates. To achieve the purpose of this study content analysis through the use of books, journal publications and available sources on the internet library. This is to give a profounder understanding of the specialization issues that surround social workers in Nigerian prisons with a view of bettering the inmate's life. The findings of this research work reveals that, lack of qualified social workers affect the rehabilitation programme aim at reforming the inmates. Also, the findings disclose poor founding and ineffective governance as responsible for the shortage staff in the prison, rigidity (bureaucratic bottle neck) and institutional failure. Issues such as corruption, nepotism, and regional sentiments were the real problems behind the unspecialized social workers in Nigerian prisons service.
\end{abstract}

Keywords: social worker, specialization, rehabilitation, prison.

\title{
Introduction
}

Social work is an educational and practice-based professional discipline that seeks to facilitate the welfare of communities, groups, families and individuals. Underpinned by theories of social science and guided by principles of social justice, right, collective responsibility, and respect for diversity, social work engages people and structures to address life challenges and enhance well-being (Forde and Lynch, 2013). Social work endeavors to promote social change and grassroots empowerment of people and aids in socioeconomic development, social cohesion, and liberation from abuse and oppression. A practicing professional with a degree in social work is called a social worker.

It is highly challenging to be a social worker, but it is a rewarding career. Social workers are responsible for assisting individuals, families, and groups of people to cope with problems they are fronting to improve their patients' lives. One of the aspects of this is teaching skills and developing apparatuses for patients to rely on to better their lives and experiences (Cipolle, 2010). Nevertheless, Cowles, (2012) said many social workers find that direct counseling of patients, families, and groups is only one little aspect of their broader set of responsibilities. Social workers will often serve as liaisons between different institutions to assist patients and collaborate with other health professionals to ensure patient wellness and recovery.

They will become acquainted with, and refer clients to, community resources. Social workers address legal issues, such as assisting with hearings and providing testimony relating to their patients in either court of law or where the clients need assistance. They also engage in research, policy development and advocacy for services (Cipolle, 2010). Moreover, social workers must maintain case history records and prepare reports on every case handled by them. Social work can be the kind of job that requires a great deal of overtime, and separating the emotional aspects of the job from the duties required can be a difficult undertaking.

Social workers are very important change agents who also ensure that the prisoners are well care for and made them to understand their challenges and are ready to solve the problems for them (Dziegielewski, 2013). As an important person, it requires dedication is to make the people aware of various problems in a community. They help to provide knowledge and to know about the main causes that affect their life in a given community.

In dealing with the assembly of challenges that social workers address, they must employ a variety of specialization depending on the job that needed to be done (Baksa, 2010). While some of these skills may be natural, some of them are improved while a social worker earns his or her bachelor's, master's or PhD degrees. Some of the qualities are enumerated below;

- Critical Thinking: Using logic and reasoning to identify the strengths and weaknesses of different challenges of the inmates and profile solutions, conclusions or approaches to a given problem.

- Active Listening: Giving full attention to what inmates are saying, taking time to understand the points being made by them, asking questions as appropriate, and not interrupting at inappropriate times (letting them air their mind on any issues that bothers them). 
- Speaking or Writing: Talking or Communicating effectively in writing as appropriate for the needs of the inmates to convey information effectively no man is an island, must be able to speak with them around in a likeminded manner (Hoffman, 2015).

- Complex Problem Solving: Classifying multifaceted complications and reading related information to develop and evaluate options and implement solutions that will enhance result from rehabilitation programme.

- Judgment and Decision Making: Considering the relative costs and benefits of potential actions to choose the most appropriate one with more effectiveness in result getting (result oriented plans)

- Coordination: Correctional rehabilitation actions in relation to the inmate's life and actions that may hinder progress or advancement reforming the inmates are coordinated (Zanca, and Dijkers, 2014).

- Service Orientation: Actively looking for ways to help inmates out of their challenges in which they seek help for why in prison, the social work are different from prison warders whose purpose most times are to punish the inmates.

\section{Objective of the Paper}

This research paper focus on this objective: to examine the specialization of social worker on the impact of prison rehabilitation programmes on the welfare of the inmates

\section{Methodology}

The research work made use of content analysis through the use of books, journal publications and available sources on the internet library. This is to give a deeper understanding of the issues on specialization of social worker on the impact of prison rehabilitation programmes on the welfare of the inmates in Nigerian prison services with a view of proffering solutions.

\section{Findings}

The findings from the research would be discussed below in relation to this work on the basic goal or role of social worker as encapsulates a particular approach or set of tasks which others can reasonably expect the worker to perform. The social worker has a variety of roles, which can be broadly categorised into three main functions: organiser, advocate, and challenger (Mathieu, Tannenbaum, Kukenberger, Donsbach, andAlliger, 2015). These can be arranged on a continuum from directive intervention to an active, but nondirective approach. The role which the social worker plays on any occasion depends on a range of factors at a given situation, but most importantly on how it can help inmates to go through prison programme well rehabilitated.

\section{Social workers as an organiser}

In the initial stages of helping a group to set up, the social worker might adopt the rather directive role of organiser, taking on responsibility for getting things started by arranging meetings, sending out publicity the type of rehabilitation programme, organising positive action measures, such as Medicare and interpreting arrangements on how inmates conduct themselves either in class setting or vocational (Schlanger, 2017).Often social workers will do much of the "behind the scenes" organization for a group, following up contacts, undertaking administrative tasks, such as book-keeping, servicing meetings, producing an orientation programme or generally ensuring that the group inmates maintain contact with reality of the general public without been cut off. Social workers are increasingly encouraged to become an organizer in mind and integrate their findings into practice.

However, there is a paucity of high-quality accessible training for social workers and critical appraisal skills. We should developed an e-learning version with this kind of training and test the effectiveness of the e-learning environment in delivering service delivery and critical appraisal skills training to social workers in comparison with old ways of training them. It seems that the role of the social worker as an organizer must often be that of creative leadership. Kim, (2010) defines leadership as "the activity of influencing people to cooperate toward some goal which they come to find desirable."

Donahue, and Zeckhauser, (2011) affirms that the community organization worker will usually give indirect rather than direct, public, or official leadership. But they must bring to the problems of his agency all the knowledge, imagination, resourcefulness, and creative craftsmanship that can command. They must often interpret, suggest, and analyze alternatives, and enter fully as a dynamic partner into a creative group process by which goals will be chosen, decisions will be hammered into shape and translated into action. The final decision will rest with a lay group; but the social worker must be a creative partner and participant in the determination of objectives as well as the expert in the application of the process of inmates rehabilitation programme. 


\section{Social workersas an advocate}

This should be a rare role for social workers, whose aim is usually to enable people to speak for themselves and develop a collective voice in negotiating situations. Sometimes, however, there are constraints or pressures which justify the worker speaking on behalf of others to argue for a position based on a degree of consultation and consensus (Hoffman, 2015). Circumstances which might support this option might be lack of time in the decision-making process before the people affected by a decision have had time to gain the confidence and skills to articulate their own views in what might be an intimidating forum.

The social worker should be careful in the role of advocate that they do not go beyond their mandate to represent the views of others in the sight of the law or the enforcement agencies (Holt, 2011).In this role, social workers fight for the rights of others and work to obtain needed resources by convincing others of the legitimate needs and rights of members of society or inmate in the prison. Social workers are particularly concerned for those who are vulnerable or are unable to speak up for themselves. Advocacy can occur on the local, county, state or national level. Some social workers are involved in international human rights and advocacy for those in need (Hoffman, 2015). With this if the specialization is engaged by the authority the inmates will tends to listen and follow the lay down rules.

However, the basic goal or role of social worker might be defined as a work function which encapsulates a particular approach or set of tasks which others can reasonably expect the worker to perform as an advocate. The social worker has a variety of roles, but this advocacy or education should be given a greater priority (Guo, and Saxton, 2014). These can be arranged on a continuum from directive intervention to an active, but nondirective approach. The role which the worker plays on any occasion depends on a range of factors at a given situation, but most importantly on how it can help other people to get things done

\section{Social workers as a challenger}

One of the chief purposes of social worker is to change things, particularly to question and combat current inequalities in the distribution in the prison. The social worker therefore sometimes has a role to play in challenging prejudices, practices or policies that affect the inmate welfare and safety in discriminating against some inmates in the prison. People often hold attitudes and assumptions about themselves and others which perpetuate disadvantage and oppression. These might be expressed through language which is offensive or through hostile or patronising behaviour (Aliyu, 2014). The social worker should challenge these (and enable others to do so for themselves) in a variety of ways, including humour, private discussion, open debate, policy proposals and modelling anti-oppressive practices. In adopting this role, the worker must also be prepared to deal with any conflicts, resentment or feelings of disempowerment that result and to recognise that the role of challenger can be both uncomfortable and controversial.

However, the social worker should usually try to move their professional relationship with the inmate to be more that of a challenger or initiator. The key aspect to this role is that the social worker is enabling the inmate he/she is working with to acquire new capabilities and to enhance their existing skills, knowledge and understanding of the general public safety (Crawley, 2013). This process might be through encouraging inmate to share these with others in the group, learning through role play or observation or through more formal training opportunities. Often this involves working closely alongside individual members of a group on a particular task, giving practical advice, support and feedback so that they eventually feel confident to perform the task on their own (Malekoff, 2015). Informal discussions or workshops also provide opportunities for people to share and develop their knowledge by reflecting on their own experience and gaining information on specific areas on public safety life (such as the workings of local government).

Moreover, this involves more interpersonal methods of working, such as counselling, advising, building selfesteem and generally encouraging inmate to work through difficult situations (Van Voorhis, and Salisbury, 2013). It might include talking through an idea or a problem with an individual or group, listening to someone's grievances, staying in touch with a member of a group who is experiencing difficulties in their life and not able to attend regularly, being a friendly and accessible point of contact between inmates in the prison or simply ensuring that inmates can make use of facilities and resources that they need in their work (such as use of available machines, technology or meeting space.)

\section{Conclusion}

It is obvious that most of Nigerian prisons are becoming criminal breeding center in the hands of untrained Nigerian prison staffs. Tragedies associated with the lives of inmates are difficult to assess in monetary terms. 
The proposed intensive and continuous introduction of social work education, with its promising features, into our schools and society system in which social worker is highly needed, deserves serious consideration by the Nigerian governments at the three levels. The training of our primary, secondary and post-secondary learners and the distance learners in social work education for caring for the inmates today means entrusting the ever growing prison population business into good hands for tomorrow better life. Time is ripe for action from the social workers when empowered by the government.

\section{Recommendation}

1. There should great advocacy for inmates to resolve crises and improved the standards of living and working in the prison;

2. Social worker should help inmates to fabricate and reestablish their self-regard and professional capacities. Offenders need one to three years' provisional managements to effectively dissuade their lives far from criminality.

3. Collaborate with other professionals to evaluate inmates' medical or physical condition and to assess their needs or refer patient, client, or family to authority to assist in recovery from mental or physical illness and to provide access to services such as financial assistance, legal aid, housing, job placement or education.

4. Counsel clients and patients in individual and group sessions to help them overcome dependencies, recover from illness, and adjust to life and investigate child abuse or neglect cases and take authorized protective action when necessary.

5. Monitor, evaluate, and record inmate's progress according to measurable goals described in treatment and care plan.

\section{References}

1. Baksa, A. (2010). Roles of social workers in a hospital setting.

2. Cipolle, S. B. (2010). Service-learning and social justice: Engaging students in social change. Rowman \& Littlefield Publishers.

3. Cowles, L. A. (2012). Social work in the health field: A care perspective. Routledge.

4. Crawley, E. M. (2013). Doing prison work. Routledge.

5. Donahue, J. D., \& Zeckhauser, R. J. (2011). Collaborative governance: Private roles for public goals in turbulent times. Princeton University Press.

6. Dziegielewski, S. F. (2013). The changing face of health care social work: Opportunities and challenges for professional practice. Springer Publishing Company.

7. Forde, C., \& Lynch, D. (2013). Critical practice for challenging times: social workers' engagement with community work. The British Journal of Social Work, 44(8), 2078-2094.

8. Guo, C., \& Saxton, G. D. (2014). Tweeting social change: How social media are changing nonprofit advocacy. Nonprofit and Voluntary Sector Quarterly, 43(1), 57-79.

9. Hoffman, K. (2015). Development of a framework to improve rehabilitation and health outcome in major trauma patients and trauma systems (Doctoral dissertation, Queen Mary University of London).

10. Holt, S. (2011). Domestic abuse and child contact: positioning children in the decision-making process. Child Care in Practice, 17(4), 327-346.

11. Kim, D. H. (2010). An effective strategy for leadership development in the cell church. Liberty University.

12. Malekoff, A. (2015). Group work with adolescents: Principles and practice. Guilford Publications.

13. Mathieu, J. E., Tannenbaum, S. I., Kukenberger, M. R., Donsbach, J. S., \&Alliger, G. M. (2015). Team role experience and orientation: A measure and tests of construct validity. Group \& Organization Management, 40(1), 6-34.

14. Schlanger, M. (2017). Prisoners with Disabilities: Individualization and Integration.

15. Van Voorhis, P., \& Salisbury, E. (2013). Correctional counseling and rehabilitation. Routledge.

16. Zanca, J. M., \& Dijkers, M. P. (2014). Describing what we do: a qualitative study of clinicians' perspectives on classifying rehabilitation interventions. Archives of physical medicine and rehabilitation, 95(1), S55-S65. 